\title{
Estimated occurrence of tobacco, alcohol, and other drug use among 12- to 18-year-old students in Panama: Results of Panama's 1996 National Youth Survey on Alcohol and Drug Use
}

\author{
Gonzalo B. González, ${ }^{1}$ Miguel A. Cedeño, ${ }^{1}$ Marcel Penna, ${ }^{1}$ \\ Luis Caris, ${ }^{2}$ Jorge Delva, ${ }^{3}$ and James C. Anthony ${ }^{3}$
}

ABSTRACT This report provides the first epidemiological evidence on tobacco, alcohol, and other drug use among school students in Panama, using data from a student survey completed in 1996. Specifically, we examine sex, age, grade level, type of school, and urban-rural variations in the occurrence of tobacco, alcohol, and other drug use. Estimates of lifetime prevalence and pastyear use of these products were obtained using data from Panama's 1996 National Youth Survey on Alcohol and Drug Use $(\mathrm{n}=6477)$. To account for the multistage sampling design of the survey, all estimates and respective standard errors are derived by the Taylor series approximation method using Epi Info 6.0 CSAMPLE software.

In general, more males, more older students, and more students in higher grades have used licit and illicit drugs, even though male-female differences tend to be small. Public-private school differences and urban-rural trends vary depending on the drug. The findings of this study are discussed in relation to the epidemiology and prevention of drug use in Panama. Based on these data, we seek to provide information to be used by the Government of Panama in its planning for prevention programs directed toward students in Panamanian schools.

The Coalition of Panama [La Coalición de Panamál, organized by the First Lady of Panama, commissioned its Ministry of Public Health to conduct a nationwide survey of school students in order to provide new evidence on

\footnotetext{
Ministry of Health, Panama City, Panama.

2 Ministry of Health, Santiago, Chile.

3 The Johns Hopkins University, School of Hygiene and Public Health, Department of Mental Hygiene, Baltimore, Maryland, United States of America. Submit correspondence and reprint requests to: James C. Anthony, Ph.D., Johns Hopkins University, School of Hygiene and Public Health, $624 \mathrm{~N}$. Broadway, 8th Floor, Baltimore, Maryland 21205 USA.
}

the dimensions of youthful drug involvement in Panama, and to supply information for the Coalition to use in planning prevention programs directed toward students in the country's schools. The purpose of this report is to present estimates about the occurrence of tobacco, alcohol, and other drug use among school-attending youths in Panama, as assessed in the country's 1996 National Youth Survey on Alcohol and Drug Use.

The National Youth Survey is the first in Panama to examine drug use and suspected determinants of drug use using a sample designed to repre- sent school-attending youths. The need for such a survey was conveyed by the above coalition as a result of Panama's drug surveillance system, which had shown an increase in drug use and drug-related problems among people seeking emergency medical care, among inmates in correctional facilities, and among people seeking substance abuse treatment (1). Additional need for a national survey also stems from the findings of two prior surveys conducted in Panama. A household survey of drug use conducted in four urban areas in Panama in 1991 and a 
school survey in the district of Changuinola in 1993 showed the percent of lifetime cocaine use to be approximately 4.4 in the early 1990s, a percent much higher than in several other Latin American countries in that same period $(2,3)$.

This apparent increase in drug use in recent years does not seem to be unique to Panama. According to two reports on drug use in Latin America by the Executive Secretariat of the Inter-American Drug Abuse Control Commission (CICAD) of the Organization of American States (OAS), drug use appears to be increasing, particularly among young persons $(4,5)$. Recent increases in cocaine use in Central America is a case in point (5). Recently documented increases in marijuana use in Chile, as well as the high incidence of smoking of pasta base (unprocessed cocaine) in the northern cities of the country, are additional examples of the complex drug problem found in Latin America (6-8).

The results of the national survey in Panama are intended to guide the allocation of resources to facilitate the development, implementation, and evaluation of preventive intervention programs targeted towards the young population of the country. This is an important task in view of the increasing use of alcohol and other drugs, and related health and psychosocial problems.

\section{MATERIALS AND METHODS}

The Panama population under study was all school-attending youths 12-18 years old in 1996, except those who had progressed to postsecondary education, that is, to the university level. The sample consisted of 6477 students selected via multistage probability sampling from 154 public and private schools, chosen to represent the urban and rural areas of the entire country. There is no $100 \%$ list of youths ages 12-18 attending school in Panama, from which a strictly random sample might be drawn. Hence, schools were sampled from a complete list of schools, and classrooms were sampled from a complete list of the schools' classrooms. Every student attending the sampled classrooms was recruited for participation. The characteristics of the survey respondents are shown in Table 1.

Assessments were administered as anonymous self-report questionnaires in each class by trained survey staff members who first introduced the survey and answered questions. The questionnaire was an adapted, Spanish-language version of the Drug Use Screening Inventory (DUSI). The DUSI was developed to assess alcohol and other drug use, school adjustment, and behavioral and psychological problems among youths in the United States (9). The DUSI was translated and adapted by investigators of the Ministry of Health in Panama in col-

TABLE 1. Demographic characteristics of students 12-18 years old participating in National Survey of Alcohol and Other Drug Use, Panama, 1996

\begin{tabular}{lcc}
\hline & \multicolumn{2}{c}{$n=6477$} \\
\cline { 2 - 3 } & $\begin{array}{c}\text { No. } \\
\text { Characteristic }\end{array}$ & $\begin{array}{c}\% \\
\text { (unweighted) }\end{array}$ \\
(weighted)
\end{tabular}

laboration with two of the authors, Luis Caris and James C. Anthony. Logistical and financial support came from CICAD and the Pan American Health Organization.

To ensure language and conceptual equivalency, the research group translated the DUSI into Spanish and then "back-translated" that document into English. The resulting, final Spanishlanguage version of this questionnaire instrument has been used extensively during the last four years in Central and South America. Furthermore, in 1994, a pilot test of the DUSI was conducted in Panama with 524 students aged 12-19 years; questions the students found to be unclear or confusing were revised in preparation for the national survey.

A total of 39 assessors were trained for a period of one week before they conducted the assessments. Supervisors closely monitored the fieldwork throughout the entire data collection period. For quality control, regional supervisors edited completed surveys before forwarding them to the national field office. This work entailed no changes in students' answers, but provided monitoring and rapid detection of missing data and unclear responses. This information then was provided as feedback to assessors so they would have uniform specifications about how to answer students' questions.

Informed consent procedures involved notifying parents and allowing either students or parents to withdraw or to skip questions. Assurances of anonymity were provided. Though parents might have kept their children home on the day of the survey in order to avoid study participation, to our knowledge no parent or student refused participation in the survey. Some students skipped sensitive questions, as seems to be common for surveys of this type. Furthermore, students were told that they could decline to participate at any time without fearing retaliation.

To measure the occurrence of drug use, students were asked the following question regarding drug use: " $i$ Has consumido (nombre de la droga) alguna vez en la vida?" ["Have you ever used (name 
of drug)?"], as well as follow-up questions, such as to assess recency of use. The lifetime experience question was asked for tobacco, alcohol, marijuana, tranquilizers, inhalants, stimulants, COcaine hydrochloride (cocaine in powder form), crack cocaine (the form that can be smoked), pasta base (coca paste), hallucinogens, and heroin. To measure recent drug use, students were asked the following question: “¿Cuántas veces has consumido (nombre de la droga) en los últimos 12 meses?" ["How may times have you consumed (name of drug) in the past 12 months?"]. This question is measured on the following 6-point scale: none (1), less than 12 times per year (2), 1-2 times per month (3), 3-9 times per month (4), 10-20 times per month (5), and more than 20 times per month (6). The above categories were recoded as "zero" if the student did not use in the past year (response category 1) and as "one" if the student had used any time in the past year (response categories 2-6). As a result of the low lifetime prevalence of drug use other than tobacco and alcohol, estimates for recent drug use were obtained solely for tobacco, alcohol, and the category of "other drugs," which refers to any one of the following substances: marijuana, tranquilizers, inhalants, stimulants, cocaine hydrochloride, crack cocaine, pasta base, hallucinogens, and heroin.

By general convention in drug use epidemiology, "lifetime prevalence" refers to the cumulative occurrence of drug experience up to and including the time of assessment. Its magnitude is conveyed by the size of a proportion (range: 0-100\%). Lifetime prevalence has the advantage of reflecting the occurrence of drug use in the group assessed during the survey fieldwork. It has the disadvantage of not reflecting the experience of potential respondents who are absent or not available for assessment when the survey is completed. Thus, as discussed later in this paper, to the extent that absenteeism or school-leaving is associated with drug use, lifetime prevalence from school surveys yields an underestimate of the actual cumulative occurrence.

All estimates of lifetime prevalence and of recent use of each drug and the respective 95-percent confidence intervals $(95 \%$ CI) were derived by the Taylor series approximation method using Epi Info 6.0 CSAMPLE software (10). This method allows for variation in sampling weights; poststratification adjustment to such known school population characteristics as age, sex, region, and public versus private; and survey "design effects" created because students are sampled within classrooms and schools rather than randomly sampled from a $100 \%$ list of all students in Panama. This is a descriptive survey without formal hypothesis testing; $P$ values are reported only as an aid to interpretation. "Corrections" for multiple comparisons are controversial in the biostatistical field (11), and they have not been applied.

\section{RESULTS}

Table 2 shows survey-based estimates for lifetime prevalence of use of the 11 drugs under investigation. The drug used by the most students is alcohol (41\%; 95\% CI $=38.3$ to 44.2$)$, followed by tobacco $(11 \%$; $95 \% \mathrm{CI}=$ 9.3 to 12.6). The most common illicit drugs are tranquilizers $(6.7 \% ; 95 \% \mathrm{CI}=$ 5.8 to 7.5$)$, inhalants $(2.4 \% ; 95 \% \mathrm{CI}=$ 1.9 to 2.9$)$, and stimulants $(1.9 \% ; 95 \%$ $\mathrm{CI}=1.4$ to 2.4 ). As shown in Table 2, fewer than one percent of the students reported using marijuana, cocaine hydrochloride, crack cocaine, pasta base (coca paste), hallucinogens, and heroin.

Table 3 shows estimates for recent use of tobacco, alcohol, and other drugs. An estimated $33.6 \%$ of students used alcohol in the year prior to assessment (95\% CI $=30.2$ to 37.1$)$, and past-year tobacco use was $8.7 \%$ (95\% $\mathrm{CI}=6.8$ to 10.6 ). The corresponding estimate for the use of other drugs was $4.6 \%(95 \% \mathrm{CI}=3.6$ to 5.5$)$.

\section{Sex Differences}

As shown in Table 4, in general, male-female differences in drug use were not appreciable, though there was a tendency for more males than females to have used licit and illicit drugs. For example, with respect to alcohol, the estimates for use were $45.5 \%$ for males and $37.0 \%$ for females. The corresponding estimates for tobacco were $12.2 \%$ for males and $9.7 \%$ for females. For tranquilizers and stimulants, the sex ratio was reversed. For example, with respect to tranquilizers, an estimated $7.3 \%$ of females had used tranquilizers, versus $6.1 \%$ of males.

Table 5 shows that male-female differences in recent tobacco, alcohol, and other drug use also were not appreciable, though more males $(9.5 \%)$ than females $(7.9 \%)$ had used tobacco and

TABLE 2. Estimates for lifetime prevalence of tobacco, alcohol, and other drug use among school students, Panama, 1996 ( $n=6$ 477)

\begin{tabular}{lrcc}
\hline & \multicolumn{3}{c}{ Estimates of prevalence $^{\mathrm{a}}$} \\
\cline { 2 - 4 } \multicolumn{1}{c}{ Drug } & No. & $\%$ & $95 \% \mathrm{Cl}$ \\
\hline Tobacco & 711 & 11.0 & $9.3-2.6$ \\
Alcohol & 631 & 41.2 & $38.3-44.2$ \\
Marijuana & 56 & 0.7 & $0.5-1.0$ \\
Tranquilizers & 437 & 6.7 & $5.8-7.5$ \\
Inhalants & 143 & 2.4 & $1.9-2.9$ \\
Stimulants & 130 & 1.9 & $1.4-2.4$ \\
Cocaine hydrochloride & 42 & 0.6 & $0.4-0.9$ \\
Crack cocaine & 34 & 0.5 & $0.3-0.7$ \\
Pasta base & 34 & 0.4 & $0.2-0.6$ \\
Hallucinogens & 48 & 0.6 & $0.4-0.9$ \\
Heroin & 25 & 0.3 & $0.2-0.5$ \\
\hline
\end{tabular}

a The numbers of drug users (No.) in the sample $(n)$ are unweighted. Estimates for prevalence proportions (\%) are weighted and poststratified to reflect the population of school students in Panama. 
TABLE 3. Estimates of recent use of tobacco, alcohol, and other drugs among school students, Panama, 1996

\begin{tabular}{|c|c|c|c|c|}
\hline \multirow[b]{2}{*}{ Drug } & \multicolumn{4}{|c|}{ Estimates of past-year use ${ }^{a}$} \\
\hline & $\begin{array}{l}\text { No. who } \\
\text { responded }\end{array}$ & $\begin{array}{c}\text { No. } \\
\text { of past users }\end{array}$ & $\%$ & $95 \% \mathrm{Cl}$ \\
\hline Tobacco & 5235 & 468 & 8.7 & $6.8-10.6$ \\
\hline Alcohol & 5481 & 1838 & 33.6 & $30.2-37.1$ \\
\hline Other drugs ${ }^{b}$ & 5098 & 249 & 4.6 & $3.7-5.5$ \\
\hline
\end{tabular}

a The number of respondents varies due to missing data for questions on alcohol, tobacco, and other drug use in the past year. The number of drug users in the sample is unweighted. Estimates for prevalence proportions (\%) are weighted and poststratified to reflect the population of school students in Panama.

b Category of "other drugs" includes marijuana, tranquilizers, inhalants, stimulants, cocaine hydrochloride, crack cocaine, pasta base, hallucinogens, and heroin.

more males $(36.7 \%)$ than females $(30.5 \%)$ had used alcohol in the year prior to the interview. The use of other drugs was greater for females (5.5\%) than for males $(3.8 \%)$, but this was due to the greater percentage of females who used tranquilizers, as indicated above.

\section{Age Differences}

A greater proportion of older students than younger students had used tobacco, alcohol, and several other illicit drugs (e.g., marijuana and cocaine hydrochloride). For example, while $32.9 \%$ of those 12 or 13 years old had consumed alcoholic beverages, the estimate for those 14-15 years old was $40.0 \%$ and for those 16-18 years old it was $55.5 \%(P=0.01)$. This consistency of age-related differences was not seen for tranquilizers, inhalants, stimulants, pasta base, or hallucinogens.

Similarly, a greater proportion of older students than younger students had used tobacco and alcohol in the past year (see Table 5). On the other hand, the use of other drugs tended to be greater among those 14-15 years old $(6.5 \%)$ than those $12-13(3.3 \%)$ and $16-18(3.3 \%)(P=0.05)$.

\section{Grade-level Differences}

The occurrence of drug use advanced in magnitude more regularly with respect to grade level than in relation to age (see Table 4). For example, an estimated $29 \%$ of students in secondary grade level 1 had consumed alcohol at least once in their lifetimes. The corresponding estimates for students in grade levels 2 and 3 were $42.3 \%$ and $59.1 \%$, respectively. Similarly, tobacco had been used by $7.0 \%$, $10.7 \%$, and $17.4 \%$ of students in secondary grade levels 1,2 , and 3 , respectively.

Recent tobacco, alcohol, and other drug use also increased with grade level. For example, the proportion of students who had used alcohol in the past year in grade level 1 was $21.5 \%$. That rose to $34.9 \%$ and $50.4 \%$ in grade levels 2 and 3 , respectively (see Table 5).

TABLE 4. Estimated lifetime prevalence of tobacco, alcohol, and other drug use by demographic characteristics (weighted percents), Panama, 1996

\begin{tabular}{|c|c|c|c|c|c|c|c|c|c|c|c|}
\hline \multirow[b]{2}{*}{ Characteristic } & \multirow{2}{*}{$\begin{array}{l}\text { Total sample size } \\
\text { (unweighted) }\end{array}$} & \multicolumn{2}{|c|}{ Tobacco } & \multicolumn{2}{|c|}{ Alcohol } & \multicolumn{2}{|c|}{ Marijuana } & \multicolumn{2}{|c|}{ Tranquilizers } & \multicolumn{2}{|c|}{ Inhalants } \\
\hline & & No. & $\%$ & No. & $\%$ & No. & $\%$ & No. & $\%$ & No. & $\%$ \\
\hline \multicolumn{12}{|l|}{ Sex } \\
\hline Female & 3073 & 300 & 9.7 & 1150 & 37.0 & 16 & 0.6 & 226 & 7.3 & 58 & 1.9 \\
\hline \multicolumn{12}{|l|}{ Age } \\
\hline $12-13$ & 3268 & 235 & 7.5 & 1064 & 32.9 & 17 & 0.4 & 173 & 5.1 & 59 & 2.0 \\
\hline \multicolumn{12}{|c|}{ Secondary grade level } \\
\hline 1 & 2612 & 174 & 7.0 & 735 & 29.0 & 11 & 0.4 & 137 & 5.3 & 42 & 1.8 \\
\hline 2 & 2148 & 232 & 10.7 & 885 & 42.3 & 20 & 0.6 & 141 & 6.4 & 47 & 2.5 \\
\hline 3 & 1713 & 305 & 17.4 & 1009 & 59.1 & 25 & 1.5 & 158 & 9.2 & 54 & 3.3 \\
\hline \multicolumn{12}{|l|}{ School type } \\
\hline Rural & 1474 & 96 & 5.6 & 416 & 30.1 & 13 & 0.7 & 83 & 5.9 & 25 & 2.7 \\
\hline
\end{tabular}


TABLE 4. (continued)

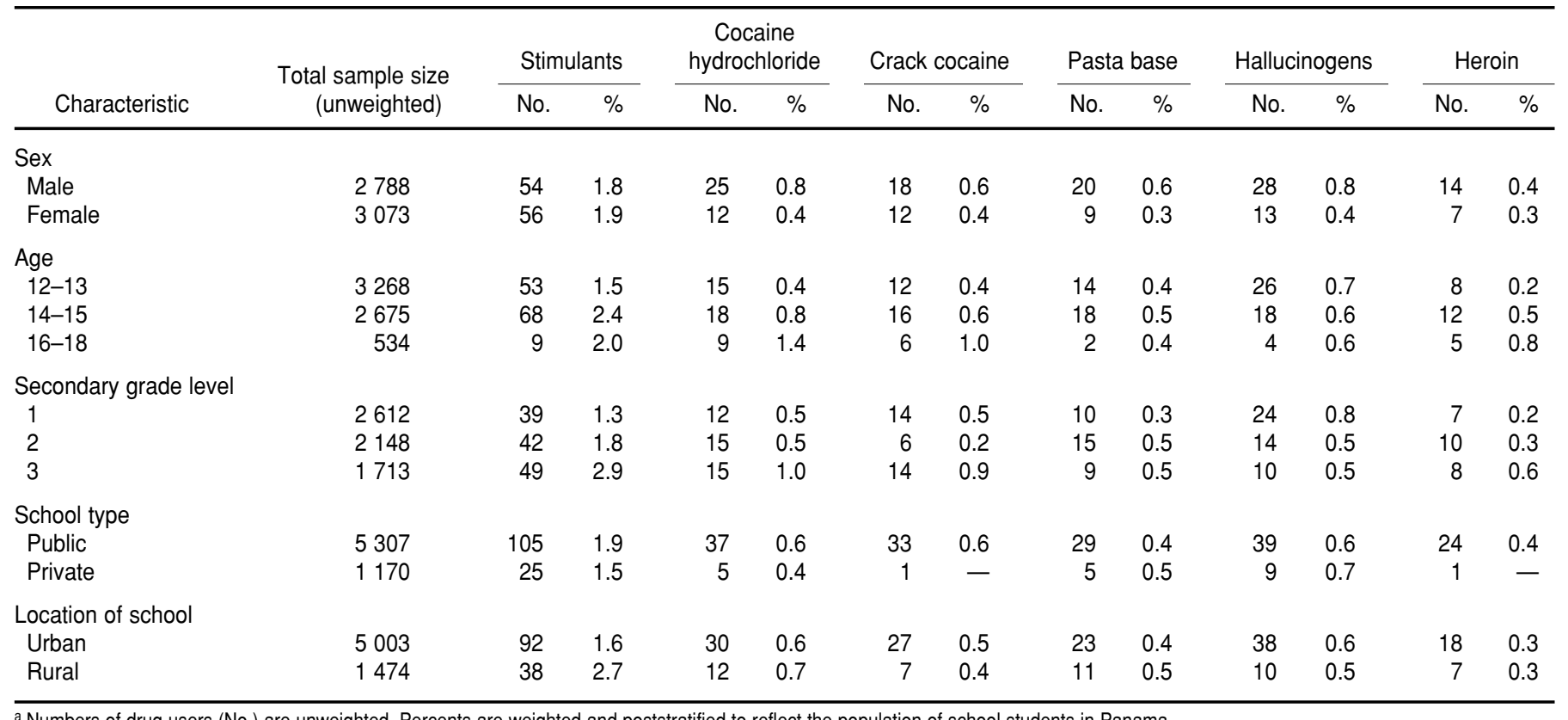

a Numbers of drug users (No.) are unweighted. Percents are weighted and poststratified to reflect the population of school students in Panama.

\section{Public versus Private Schools}

As shown in Table 4, alcohol use was much more likely to have occurred among private school students $(57.7 \%)$ than among public school students $(38.4 \%)(P=0.01)$. The same pattern was observed for the use of tobacco, inhalants, and tranquilizers. More private school students reported tobacco use than public school students $(21.8 \%$ versus $8.8 \%, P=0.01$ ), and private school students were also more likely to have used inhalants $(3.4 \%$ versus $2.2 \%, P=0.05)$. Finally, a greater proportion of students in private school $(8.9 \%)$ than in public schools $(6.2 \%)$ had used tranquilizers $(P=0.01)$. Publicprivate school differences on the use of other drugs (e.g., heroin and stimulants) were not appreciable $(P>0.05)$.

Table 5 shows that recent use of tobacco, alcohol, and other drugs was more common among private school students. The difference in the use of other drugs between public and private school students was statistically significant by conventional standards $(4.2 \%$ versus $6.8 \%$, respectively, $P=$ $0.01)$, though it was smaller than that observed for tobacco $(6.4 \%$ for public versus $19.9 \%$ for private school students, $P=0.01)$ and alcohol $(31.1 \%$ for public versus $46.2 \%$ for private school students, $P=0.01$ ).

\section{Urban versus Rural Schools}

Experience with tobacco and alcohol was substantially higher in urban areas than in rural areas (see Table 4). The most striking differences involved tobacco and alcohol: an estimated $12.4 \%$ of students in urban areas had smoked tobacco versus an estimated $5.6 \%$ in rural areas. The corresponding estimates for alcohol use were $44.2 \%$ for urban students and $30.1 \%$ for rural students. With respect to the other drugs, no urban-rural differences were striking.

Similarly, a greater percentage of students attending urban than rural schools had recently used tobacco (9.8\% versus $4.1 \%, P=0.01)$ and alcohol $(35.3 \%$ versus $26.5 \%, P=0.01$ ) (see Table 5). Urban-rural differences in past-year use of other drugs were negligible $(P>0.05)$.

\section{DISCUSSION}

The evidence from this study, based upon the first-ever nationally representative sample survey in Panama of students 12-18 years old, is consistent with evidence from many other places. Specifically, the evidence tends to show more males than females using alcohol, tobacco, and inhalants. Students in higher grade levels and those in urban schools were more likely to have started using drugs. Public school students were less likely than private school students to have started drug use, a finding consistent with data from similar studies in other Latin American countries (12-15). There is a consistent pattern of greater alcohol, tobacco, and illicit drug use among males than among females. However, there might be important gender differences from country to country. For instance, in Panama more females than males use tranquilizers, but in Colombia the difference is not statistically significant. In Chile more females than males use tobacco, a pattern also true for some regions of Brazil (13). Our findings also show a 
TABLE 5. Estimates for past-year use of tobacco, alcohol, and other drugs by demographic characteristics, Panama, 1996

\begin{tabular}{|c|c|c|c|c|c|c|c|}
\hline \multirow[b]{2}{*}{ Characteristic } & \multirow{2}{*}{$\begin{array}{l}\text { Total no. of } \\
\text { respondents } \\
\text { (unweighted) }\end{array}$} & \multicolumn{2}{|c|}{ Tobacco } & \multicolumn{2}{|c|}{ Alcohol } & \multicolumn{2}{|c|}{ Other drugs ${ }^{b}$} \\
\hline & & No. & $\%$ & No. & $\%$ & No. & $\%$ \\
\hline \multicolumn{8}{|l|}{ Sex } \\
\hline Male & 2228 & 227 & 9.5 & 887 & 36.7 & 85 & 3.8 \\
\hline Female & 2476 & 202 & 7.9 & 819 & 30.5 & 139 & 5.5 \\
\hline \multicolumn{8}{|l|}{ Age } \\
\hline $12-13$ & 2679 & 153 & 6.0 & 702 & 25.1 & 91 & 3.3 \\
\hline $14-15$ & 2191 & 270 & 11.5 & 937 & 41.0 & 144 & 6.5 \\
\hline $16-18$ & 365 & 45 & 12.7 & 199 & 51.7 & 14 & 3.3 \\
\hline \multicolumn{8}{|c|}{ Secondary grade level } \\
\hline 1 & 2101 & 106 & 5.3 & 470 & 21.5 & 71 & 3.2 \\
\hline 2 & 1735 & 155 & 8.9 & 616 & 34.9 & 79 & 5.1 \\
\hline 3 & 1395 & 207 & 13.8 & 751 & 50.4 & 98 & 6.4 \\
\hline \multicolumn{8}{|l|}{ School type } \\
\hline Public & 4194 & 276 & 6.4 & 1328 & 31.1 & 174 & 4.2 \\
\hline Private & 1041 & 192 & 19.9 & 510 & 46.2 & 75 & 6.8 \\
\hline \multicolumn{8}{|l|}{ Location of school } \\
\hline Urban & 4210 & 412 & 9.8 & 1561 & 35.3 & 201 & 4.6 \\
\hline Rural & 1025 & 56 & 4.1 & 277 & 26.5 & 48 & 4.9 \\
\hline
\end{tabular}

a The number of respondents varies for the categories of alcohol use and "other drugs" use due to missing values. The number of drug users in each category (No.) is unweighted. Estimates for prevalence proportions (\%) are weighted and poststratified to reflect the population of school students in Panama.

b The category of "other drugs" includes marijuana, tranquilizers, inhalants, stimulants, cocaine hydrochloride, crack cocaine, pasta base, hallucinogens, and heroin.

greater occurrence of alcohol, tobacco, and other drug use among private school students as compared to those in public schools. This finding also is consistent with findings from similar studies conducted in other Latin American countries $(13,14)$. The authors have hypothesized that students in private schools are of higher socioeconomic status and may have more purchasing power and thus may be more able to afford alcohol, tobacco products, and illegal drugs. The reasons for these differences in student drug use observed in Latin America remain understudied; future studies should investigate them more deeply.

Before a more detailed discussion, findings from this report can be viewed in light of several limitations. First, the data are based on retrospective selfreports of drug use. The use of selfreports may have introduced errors in recall and perhaps a socially desirable response tendency. The use of additional measurement methods (e.g., bioassays) might assist in establishing the validity of the responses, but they tend to be impractical in school surveys (16). A review of recent research on the validity of self-reported drug use and the methodological advances undertaken to reduce error in estimates of drug use concluded that the use of self-report is less valid for more stigmatized substances, such as cocaine, and for more recent drug use (17-19). These and other reports suggest that one viable alternative to assessment of drug use might be the use of hair analysis, saliva cotinine assessments, or other bioassay validation methods (17). Another strategy suggested to minimize response bias is the use of audio computer-assisted self-interviewing (audio-CASI). Audio-CASI technology involves using a computer to administer a survey in an audio format and record responses without the involvement of the assessor. In a recent study of drug use among adolescent males in the United States of America, researchers utilized the audioCASI method and a standard selfadministered questionnaire to obtain estimates of the prevalence of injecting drug use (20). These investigators found that respondents using the audio-CASI method were three times more likely to report injection drug use than respondents using the standard self-administered questionnaire; however, it is not clear that greater reporting is equivalent to more accurate reporting. The results of this and other studies demonstrate the need for more research on methods such as hair analysis or computer-assisted technology that might increase the accuracy of survey estimates. However, we are most likely many years from use of these expensive (and sometimes invasive) methods in school surveys of student drug use with sample sizes in the thousands, at least in the poorer countries of the Region of the Americas, where research and surveillance resources are in short supply. In this regard, we note the utility of the "Monitoring the Future" school surveys in the United States (26) and similar surveys in Canada, where there has been complete reliance upon self-report methods.

A second limitation is that this survey provides estimates of drug use for school-attending youths only. Given the high dropout rates among intermediate school students in Panama (21), it is possible that drug use among Panama's total population of youths is underestimated when surveys are based on school sampling frames. In Panama, there were an estimated 137054 students in public and private schools attending the grade levels under study. Though not part of the population under study, approximately $9 \%$ of the school age population in Panama does not attend school (22). Future studies that investigate the extent of drug use among school dropouts are needed to obtain a more accurate assessment of youth drug involvement in Panama. Third, a number of students skipped the question on recent drug use that asks about frequency of drug use in the past 12 months for each of the 11 drugs listed in Table 2. This problem raises questions about the validity and reliability of the measure for recent drug use. To examine this problem more carefully, future surveys should include a sepa- 
rate question for each drug and ask students whether they have used any of them in the past 12 months. This question can then be followed by questions on frequency of use for each of the drugs in the past year.

Notwithstanding these limitations, these findings have implications for the Panamanian drug prevention and policy efforts. Primarily, these efforts concentrate on preventing initiation of alcohol and tobacco use as a means to avert health and social problems commonly associated with the use of these or other substances. However, it is of concern that the apparent risk of developing alcohol or other drug problems is increased for persons who start using these substances at an earlier age (e.g., before the age of 15 versus 18-21) $(23,24)$. Moreover, at least in some samples, use of tobacco and alcohol runs in advance of use of such other drugs as marijuana (25).

It is important to note that fewer than one percent of the students participating in the survey indicated they had ever used marijuana, cocaine hydrochloride, crack cocaine, heroin, or hallucinogens. These findings are in contrast to trends observed for the Panamanian population groups in the surveillance data based on emergency room and incarcerated samples. Whether these apparent differences between population segments are due to variation in the sample compositions or validity of self-report methods remains on the agenda for future research. In addition, the 1996 evidence provides a baseline against which to gauge future trends, even if there is some degree of underestimation in self-report surveys.

One of the most interesting results from this survey involves tranquilizer use, which is seen primarily among females. Students in Panama are much more likely to have started using tranquilizers than those at comparable grade levels in the United States (26). Anecdotal reports suggest a practice in Panama, also somewhat common in other countries in Latin America, in which parents give their children tranquilizers when the youths are experiencing stressful circumstances. Future studies are needed to clarify this situation and perhaps to impose greater restrictions upon the availability of these tranquilizers.

The observed prevalence estimates for illicit drug use create a unique opportunity for leadership to mobilize and concentrate efforts on primary prevention activities in Panama. These activities might help to maintain the observed low occurrence rate of illicit drug use. Or, if the true values are larger than those reported here, then the prevention efforts can help to stabilize this situation, prior to reductions in drug use prevalence. The array of available prevention interventions is broad. They include school- and community-based prevention programs, as well as family- or individuallyoriented programs that can be used to target such different risk factors as association with deviant peers, family inattention, and drug availability (27-30). However, we suggest caution in transplanting prevention programs from other countries to Panama and recommend that careful outcome and process evaluation be conducted when implementing any prevention program.

In conclusion, the observed occurrence of alcohol and tobacco use, even at the lower school grade levels studied in the survey, makes it important to enhance primary prevention activities in Panama. Curtailing the incidence of licit and illicit drugs today is important in order to prevent an increase in the number of youths who are engaged in high-risk behaviors, such as unsafe sex. These behaviors may lead to other detrimental and serious consequences, including infection with the human immunodeficiency virus or other sexually transmitted diseases. Findings from the present survey present the leadership in Panama with an opportunity to target prevention efforts among school-aged youths, before drug use and other public health problems related to drug consumption become more prevalent.

Acknowledgements. This project was supported by the United Nations Educational, Scientific, and Cultural Organization (UNESCO), the InterAmerican Drug-Abuse Control Commission of the Organization of American States (CICAD/OAS), the Pan American Health Organization (PAHO), the "Coalición de Panamá por una Comunidad Libre de Drogas, Despacho de la Primera Dama de Panamá," and training grant T32DA07292 from the U.S. National Institute on Drug Abuse.

\section{REFERENCES}

1. Ministerio de Salud de Panamá. Vigilancia epidemiológica del uso de sustancias psico-activas en Centroamérica, República Dominicana y Panamá. Organización de Estados Americanos, Organización Panamericana de la Salud, y MSP; 1996.

2. Centro de Estudios Latinoamericanos y Proyecto Narcotics Awareness and Education. Resultados del primer estudio epidemiológico sobre prevalencia y actitudes del uso de drogas en el área urbana de Panamá [unpublished report]. Departamento de Investigación y Desarrollo de la Agencia de los Estados Unidos para el Desarrollo Internacional; 1991.

3. Cruz Blanca Panameña. Resultados de la primera encuesta de consumo de alcohol y otras drogas realizada en la provincia de Bocas del Toro [unpublished report]. Cruz Blanca Panameña y el Centro de Estudios de Prevención de la Universidad de Colorado; 1993.

4. Executive Secretariat of the Inter-American Drug Abuse Control Commission of the Organization of American States. Sistema inter- americano de datos uniformes sobre consumo de drogas, volumen I: América del Sur. CICAD/OAS; 1997.

5. Executive Secretariat of the Inter-American Drug Abuse Control Commission of the Organization of American States. Sistema interamericano de datos uniformes sobre consumo de drogas, volumen III: América Central, Panamá y República Dominicana. CICAD/OAS; 1997.

6. Chile, Ministerio del Interior, Consejo Nacional para el Control de Estupefacientes. 
Consumo de drogas en Chile: síntesis de los principales estudios y datos estadísticos. CONACE; 1996.

7. Chile, Ministerio del Interior, Consejo Nacional para el Control de Estupefacientes. Segundo informe annual sobre la situación de drogas en Chile. CONACE; 1997.

8. Caris, L. Tabaco, alcohol y drogas. Ministerio de Salud, Chile. 1998. Available from: URL: http://www.minsal.cl

9. Tarter RE, Hegedus AM. The Drug Use Screening Inventory: Its applications in the evaluation and treatment of alcohol and other drug abuse. Alcohol Health and Research World 1991;15(1):65-75.

10. Dean AG, Dean JA, Coulombier D, Brendel KA, Smith DC, Burton AH, et al. Epi Info, Version 6: A word processing, database, and statistics program for epidemiology on microcomputers. Atlanta, Georgia: U.S. Centers for Disease Control and Prevention; 1994.

11. Rothman KJ. Modern epidemiology. Boston, MA: Little, Brown, and Company; 1986.

12. Torres Y, Maya Mejía JM, Murelle L. Estudio nacional de consumo de sustancias psicoactivas y factores asociados. Estudiantes de educación secundaria y media. Colombia. Colombia: Viceministerio de la Juventud; 1996.

13. Galduróz JCF, Regina Noto A, Carlini EA. Tendencias do uso de drogas no Brasil: Síntese dos resultados obtidos sobre o uso de drogas entre estudantes do $1^{\circ} \mathrm{e} 2^{\circ}$ graus em 10 capitais Brasileiras (1987-1989-1993-1997). Universidade Federal de Sao Paulo, Escola Paulista de Medicina, Centro Brasileiro de Informaçoes sobre Drogas Psicotrópicas; 1997.

14. Alcaraz del Castillo F, Soliz Vázquez RM, Zuaso Yujra J. Consumo de alcohol, tabaco, cocaína y otras drogas en Bolivia. Bolivia: Centro Latinoamericano de Investigación Científica; 1998.

15. Caris, L. Informe preliminar del segundo estudio nacional del consumo de alcohol, tabaco y drogas en escolares año 1997. Chile. Ministerio de Educación, Ministerio de Salud, Consejo Nacional para el Control de Estupefacientes y Fundación Paz Ciudadana; 1998.

16. Anthony JC. Do I do what I say?: A perspective on self-report methods in drug dependence epidemiology. In: Stone A, Turkkan J, Bachrach CA, Cain V, Jobe JB, Kurtzman H, eds. Science of self-report: Implications for research and practice. Hillsdale, NJ: Lawrence Earlbaum Associates, Inc. In Press.

17. Harrison L, Hughes A. Introduction-The validity of self-reported drug use: Improving the accuracy of survey estimates. In: Harrison L, Hughes A, eds. The validity of self-reported drug use: Improving the accuracy of survey estimates. U.S. Department of Health and Human Services (NIH Pub. No, 97-4147) (National Institute on Drug Abuse Research Monograph No. 167); 1997:1-16.

18. Harrison L. The validity of self-reported data on drug use. Journal of Drug Issues 1995; 25(1):91-111.

19. United States of America, General Accounting Office. Drug use measurement: Strengths, limitations, and recommendations for improvement [unpublished report]. Report to the Chairman, Committee on Government Operations, U.S. House of Representatives (GAO/ PEMD-93); 1993.

20. Turner $\mathrm{CF}, \mathrm{Ku} \mathrm{L}$, Rogers SM, Lindberg LD, Pleck JH, Sonenstein FL. Adolescent sexual behavior, drug use, and violence: Increased reporting with computer survey technology. Science 1998;280:867-871.

21. Reddy MA. Statistical abstract of the world. New York: Gale Research Inc; 1994.

22. Pan American Health Organization. Health in the Americas, volume II. Washington, D.C.: PAHO; 1998

23. Anthony JC, Petronis, KR. Early-onset drug use and risk of later drug problems. Drug Alcohol Depend 1995;40(1):9-15.
24. Grant BF, Dawson DA. Age of drinking onset predicts future alcohol abuse and dependence. J Subst Abuse 1997;9:103-110.

25. Kandel DB, Yamaguchi K, Chen K. Stages of progression in drug involvement from adolescence to adulthood: Further evidence for the gateway theory. J Stud Alcohol 1992;53: 447-457.

26. Johnston LD, O'Malley PM. National survey results on drug use: The Monitoring the Future Study. Available from: URL:http://www.isr. umich.edu/src/mtf/

27. Hawkins J, Catalano R, Miller J. Risk and protective factors for alcohol and other drug problems in adolescence and early adulthood: Implications for substance abuse prevention. Psychol Bull 1992;112(1):64-105.

28. Grover PL. Preventing substance abuse among children and adolescents: Family centered approaches. U.S. Department of Health and Human Services, Substance Abuse and Mental Health Administration, Center for Substance Abuse Prevention 1998. (U.S. DHHS Publication No. 3223-1998).

29. Zucker R, Boyd G, Howard J., eds. The development of alcohol problems: Exploring the biopsychosocial matrix of risk. U.S. Department of Health and Human Services; (Research Monograph No. 26.) (National Institutes of Health Publication No. 94-3495).

30. Botvin GJ, Schinke S, Orlandi MO, eds. Drug abuse prevention with multiethnic youth. Thousand Oaks, CA: Sage Publications; 1995.

Manuscript received on 23 February 1998. Revised version accepted 11 December 1998
RESUMEN

Uso estimado de tabaco, alcohol y otras drogas en estudiantes panameños de 12 a 18 años: resultados de la Encuesta Nacional de Panamá sobre el Uso de Alcohol y Drogas en la Juventud
Este informe presenta las primeras pruebas epidemiológicas del consumo de tabaco, alcohol y otras drogas en alumnos de escuelas panameñas, usando datos obtenidos mediante una encuesta estudiantil completada en 1996. En particular hemos examinado las diferencias por sexo, edad, grado escolar, tipo de escuela y residencia urbana o rural en el uso de tabaco, alcohol y otras drogas. Se estimaron la prevalencia vitalicia y el consumo previo de estos productos a partir de una encuesta nacional de la juventud efectuada en 1996 ( $n=6$ 477). Debido al diseño muestral multietápico aplicado en la encuesta, todas las estimaciones y sus respectivos errores estándar se derivaron por el método de Taylor de series aproximadas aplicando el programa Epi Info 6.0 CSAMPLE.

En general, los varones, los alumnos de mayor edad y los alumnos de grados superiores fueron los que mayormente habían consumido drogas lícitas e ilícitas, aunque fue pequeña la diferencia entre varones y hembras. Las difrencias entre alumnos de escuelas públicas y colegios privados y las tendencias observadas en habitantes de zonas urbanas frente a los de zonas rurales variaron según el tipo de droga. Los resultados de este estudio se examinan a la luz de la epidemología y prevención del consumo de drogas en Panamá. Partiendo de estos datos, esperamos poder proveer al Gobierno de Panamá información que le sea útil para planificar programas de prevención dirigidos a alumnos de escuelas panameñas. 